\title{
Bridging community associations in post-conflict Burundi: the difficult merging of social capital endowments and new 'institutional settings' *
}

\author{
Thomas Vervisch \\ Conflict Research Group, Ghent University, Universiteitsstraat 8, gooo \\ Ghent, Belgium \\ Email: thomas.vervisch@ugent.be
}

and

KRISTOF TITECA

Research Foundation - Flanders (FWO), Institute of Development Policy and Management, University of Antwerp, Belgium

Email: kristof.titeca@ua.ac.be

A B S T R A C T

Associations have been labelled the main 'building blocks' for creating social capital. It has been argued that community associations need to transform 'bonding' into 'bridging' ties to 'reach out' while also creating 'linking' ties to 'scale up'. External development actions follow a reverse logic in promoting these associations: they assume that linking ties with the external intervener will reinforce prior social capital endowments. This article highlights the inherent difficulties of such a 'social engineering' approach in the context of post-conflict reconstruction, describing three development interventions in the north of Burundi. It defines the process of 'institutional syncretism'-merging local with global institutional settings - as a key element to social capital building. The findings illustrate how the three interventions failed to reach this objective, and

* We wish to thank Koen Vlassenroot and Johan Braeckman for their comments on an earlier version of the paper. 
question 'bridging' associations as 'universal blueprints' for restoring social cohesion within the liberal peace model for post-conflict reconstruction.

Associations have been labelled the main 'building blocks' for creating social capital. The reconciliatory nature of bridging associations - uniting groups in society that opposed each other during conflict - is welcomed in post-conflict situations (Colletta \& Cullen 2000a, 2000b). Social capital literature argues that community associations need to transform bonding into bridging ties to 'reach out', while also creating linking ties to 'scale up' the impact of the associations (Titeca \& Vervisch 2008; Woolcock 2002). However, it is not self-evident that social capital can be created from the outside. When external development agencies promote the creation of associations they follow a reverse logic, assuming that linking ties with the external intervener will create or reinforce locally produced social capital endowments.

The article examines this 'social engineering' approach, presenting a case study of three interventions by non-governmental organisations (NGOs) in post-conflict Burundi. Burundi is slowly emerging from a civil war that lasted over ten years. ${ }^{1}$ After three decades (1960s-9os) of authoritarian and military rule by the ethnic Tutsi minority, the first democratically elected Hutu president was murdered soon after his appointment in I993. In the civil war that followed, approximately 300,000 people lost their lives (Lemarchand 2009). Now, following a transition period that led to the 2005 elections, Burundi finds itself in a post-conflict reconstruction phase, featuring many of the external interventions noted above. The impact on social capital of these interventions will be analysed in terms of their success in creating bridging community associations.

The remainder of the article is structured as follows. First, it enumerates the arguments as to why community associations are seen as 'building blocks' for social capital, and how in particular bridging community associations fit into the liberal peace model for post-conflict reconstruction. Second, it presents a brief discussion of the 'constructability' of social capital, while also referring to the critical civil society literature. Third, after outlining the state of Burundi and its historical social capital endowments, it discusses the three development interventions. All three interventions illustrate their failure to initiate a process of 'institutional syncretism' (Galvan 2007), and question 'bridging' associations as 'universal blueprints' for restoring social cohesion within the liberal peace model for post-conflict reconstruction. 
The strong link between social capital and civil society is one of the main consequences of Robert Putnam's work. He equates social capital with horizontal associations, in what he calls 'networks of civic engagement' (Putnam I993: I7I). These associations have been labelled the main 'building blocks' of social capital, which Putnam (1995: 664-5) defines as 'the features of social life - networks, norms and trust - that enable participants to act together more effectively to pursue shared objectives'. The equation between social capital and community associations has tempted some policy makers to oversimplify the debate. Many define a vibrant civil society as the 'missing link' (Grootaert 1998) to economic development and democracy. Community associations rapidly became promising new 'actors' in the 'development industry'. 'Membership in groups with particular characteristics' (Narayan I997: vii) became one of the main proxy measures to build social capital. For policy makers, these studies provide an easy solution - building community associations means building social capital - and an easy way to measure the progress and success of their policies (predicated simply on 'How many new associations were built or strengthened?').

With regard to post-conflict reconstruction, in particular the potential bridging character is valued as positive (Pickering 2006): conflict is linked to high stocks of bonding and low stocks of bridging social capital (Colletta \& Gullen 2000a, 2000b). Whereas bonding capital refers to exclusive solidarity based on ethnicity, religion, cast or class, bridging capital refers to inclusive solidarity, uniting people from different backgrounds (Woolcock \& Narayan 2000). Community associations are labelled as instruments 'par excellence' to transform this 'exclusive' bonding solidarity within groups into more 'inclusive' bridging solidarity between these groups. In this respect, economic and social reconstruction efforts will only be effective if they involve and bridge between different social groups (Colletta et al. 1996; Fischer 2004). A particular case of group integration is after ethnic conflict. Institutions fostering repeated inter-ethnic interaction while addressing practical concerns support reconciliation between ethnic groups (Pickering 2006: 79), for example an association in which Hutu and Tutsi widows work together after the Rwandan genocide (Colletta \& Gullen 20oob: II3). This explains why multi-ethnic community associations are seen as 'agents of peace' (Varshney 200I: 363 ), as they increase the trust between and within communities in post-conflict situations (Belloni 2008: 193). 
In sum, this liberal-pluralist conception of civil society and 'bridging' associations can be framed within the broader 'liberal peace' model. The goal of this model is the rapid modernisation of societies through the construction of new and liberal institutions (Daley 2008: 34). Donor interventions therefore place great emphasis on civil society strengthening. These civil society organisations are meant to build social capital in two particular ways (Paffenholz 2009). On the one hand, in-group socialisation should support the practice of democratic values and attitudes within society. On the other hand, and this is specific to post-conflict settings, they should facilitate cooperation through joint development activities between adversarial groups in society, resulting in inter-group social cohesion or the much praised 'bridging' social capital. There is therefore a great emphasis on the quantitative growth of these associations (Belloni 200 : I68; Henderson 2002), and as Duffield (2002) and Goodhand (2006) indicate, NGOs in particular are expected to build social capital and strengthen local civil society, which turns their aid into a strategic tool for conflict resolution and social reconstruction.

This leads us to the following two fundamental questions for social capital. First, how can social capital be constructed? Second, how can external development interventions play a role in this process? As argued above, the latter may seem a rhetorical question, as the 'constructability' of social capital in policy circles no longer seems to be an issue: it is seen as a 'technical fix' which can be constructed regardless of the context. Of course, there is less consensus about this among social capital scholars. This debate is briefly discussed in the next section.

THE 'CONSTRUCTABILITY' OF SOCIAL CAPITAL REVISITED

Putnam's (1993) path dependency model argues that the construction of social capital is the outcome of historical processes. In his Italian study, Putnam illustrates this with a historical account of the republican tradition to explain the high degree of 'civicness' in the Italian city states. The presence of such social capital endowments is then perceived as vitally important for the further development of social capital in societies. This 'endowment view' (Evans I996: i 124) gives an idea of social capital stocks emerging over long periods of time, leaving little room for change. Others point to the fact that social capital patterns are neither stable nor given, and that contemporary institutional arrangements can facilitate or erode the production and maintenance of social capital stocks (Hooghe \& Stolle 2003: 6). In this view, prior endowments of social capital are not the key constraining factor, as 'soft technologies' on an organisational level and 
'institutional entrepreneurship' can build new stocks of social capital or change existing stocks (Evans I996: I I24). For Evans, the critical question under this 'constructability view' is how existing endowments of social capital can be 'scaled up' to increase the efficiency of solidarity ties and societal action. Supporters of this view consider both the state and civil society as two main actors capable of supporting this 'scaling-up' process (Fox 1996). The two views are not completely opposed, as the discussion is more subtle and handles the relative importance of prior 'endowments' on the one hand and the facilitating 'institutional settings' on the other.

This helps us to sharpen our analysis of external development interventions. It puts the process of 'institutional syncretism' (Galvan 2007) at the heart of the debate. Institutions can be defined in terms of layered social structures (organisation, networks etc.), the norms (or 'rules of the game') that govern these structures, and underlying cultural markers (social identities) (Bastiaensen et al. 2002: Io ; 2005: 980). Galvan (2007: 62-3) defines institutional syncretism as 'the creative recombination of institutional elements (organisational structures, rules, habits and values) derived from more than one socio-cultural origin (e.g. from local "tradition" and globalised "modern" models)'. Whereas Galvan explores the capacity of the local population (the 'recipients' of institutional engineering) to recombine these institutional settings from different origins, we focus more on this capacity from the 'supply side'; as such, the main question is if and how well development agencies can play the role of 'institutional entrepreneur', and introduce new globalised and 'modern' 'institutional settings', which are able to syncretise with prior local 'traditional' social capital endowments.

As noted in the sections above, community associations are considered an excellent and widely used example of a new 'institutional setting' for constructing social capital. From an 'endowment perspective', the assumption is that community associations follow a linear progression: transforming bonding into bridging ties to 'reach out' while also creating linking ties to 'scale up' the impact of social capital endowments (Titeca \& Vervisch 2008). These steps are clarified for example in the roles Brown (I99I) allocates to organisations in sustainable development: the ability to maintain local effort, the ability to create bridging ties to other organisations and the ability to influence politics through vertical ties. However, when external development interventions promote the creation of such associations they follow a reverse logic, assuming that linking ties with the external intervener will reinforce prior social capital endowments. Through the introduction of linking social capital-the capacity of the local population to leverage global, 'modern' or exogenous 'ideas, 
information, and resources' (Woolcock 2002: 26) from an external agent - the aim is to reinforce existing local, 'traditional' or endogenous, bonding, bridging and linking social capital endowments. This reveals a clear 'constructability view', identifying the external agency as a social engineer using institutional 'soft technologies' (Evans i996: II24). These 'soft technologies' refer to both the exact content of the induced linking social capital (e.g. financial resources, knowledge transfer etc.) and the new 'institutional setting' in which these are made accessible (e.g. community associations).

In other words, institutional syncretism highlights how external interventions should be seen as a fragile process: on the one hand, they cannot be purely externally driven 'constructability' exercises, but should rely on local dynamics of change; yet, and on the other hand, these interventions should also be careful with local 'endowments' of social capital, as each of them has its particular difficulties.

Strongly externally driven support has particular dangers for the construction of social capital and community associations. This becomes clear when looking at the critical civil society literature, in which three particular problems are identified in external support to community associations. First, by considering the support to community associations as a technical enterprise, the latter are seen as apolitical and decontextualised 'universal blueprints', whereas community associations are deeply embedded in the social and political context. Political and societal power therefore may have a negative impact on the political efficacy and participation of the association, and may disempower rather than empower its members (Beck 2003; Blaney \& Pasha I993). In other words, successful support for community associations needs to take into account local realities rather than considering this a technical and decontextualised 'fix'. Second, external development interventions enable association leaders to build up outside legitimacy and, as a consequence, prevent the autonomous evolution of leadership on total accountability vis-à-vis the association members (Platteau \& Gaspart 2003: I700; Bierschenk et al. 2000). In other words, linking social capital, which is central to the 'constructability view', has potential dangers. As identified by Evans (1996), linking capital has the potential to produce synergy between local dynamic processes of social capital and the policies of external interveners, including the state and (inter)national civil society. However, this is also potentially dangerous: 'gatekeepers' who monopolise this linking capital (resources, contacts with external funders and so on) can negatively impact the association when they are not held to account by the rest of the association, leading to authoritarian tendencies or corruption. In other words, the impact of the 
external intervention can be strongly negative when the association lacks sufficient bonding and bridging social capital endowments to handle this externally induced linking social capital (Titeca \& Vervisch 2008). Third, by using civil society associations (such as community associations) as cheap implementing agents for donor agents, these associations become passive beneficiaries instead of empowered citizens, concerned to implement the donor's changing priorities and dependent on the continuous presence of the international community. In such a situation, the strong reliance of civil society associations on donor aid has a strongly negative effect on them, and limits their potential for reconciliation and democratisation (Belloni 200ı: I75-6; Hulme \& Edwards I996; Robinson I995). There is also the sustainability problem: associations may cease to exist when the funding ends, and, inversely, may only arise because there is a funding opportunity (Ottaway \& Chung 1999). Lastly, donors may harm the spontaneous development of bridging associations by imposing specific goals (Pickering 2006). In summary, these multiple criticisms highlight the danger of 'institutional monocropping', or 'the imposition of blueprints based on idealized versions of Anglo-American institutions, the applicability of which is presumed to transcend national circumstances and cultures'. There is therefore a need to 'increase rather than diminish, local input and experimentation' (Evans 2004: 30).

The syncretisation of external 'institutional settings' with local social capital endowments remains however a fragile process, as local endowments of social capital are not automatically positive. Putnam (I993) has made considerable efforts to explain the difference between 'bad' vertical patron-client networks that are integrated in the 'amoral familism' present in the south of Italy, and 'good' horizontal civic networks which, according to Putnam, explain the working of democracy in northern Italy. Therefore, Putnam (2004) seeks to distinguish between 'responsive' and 'unresponsive' linking social capital, in which the 'unresponsive' form can lead towards nepotism, corruption and suppression (Szreter \& Woolcock 2004). In other words, social capital has a 'down' or 'dark' side (Portes \& Landolt 1996) or may be 'perverse' (Rubio I997). Institutional syncretism with 'soft' technologies may be unable to change these 'unresponsive' forms of social capital, and may therefore even 'scale up' corruption, nepotism and suppression. For external development actors, the real challenge therefore lies in developing new 'institutional settings' that are 'soft' enough to adapt to prior social capital endowments, but 'strong' enough to change or reinforce these endowments to bring positive results. This fragile process puts institutional syncretism at the centre of the debate on social capital building. As Galvan (2007: 70) explains: 'institutional 
syncretism ... is neither the wholesale adoption of externally derived, "modern" rules and norms, nor the unreflexive reproduction of existing local or "traditional" regularised habits and practices'. These challenges are at the heart of external interventions to build social capital, as will become clear throughout the case studies in the Burundian context, all three of which failed in this fragile process.

\section{SOCIAL CA PITAL ENDOWMENTS IN B UR UNDIAN SOCIETY}

Burundi does not have a strong associational tradition. First, Burundian society was much more vertically than horizontally stratified, with patronclient ties to a great extent determining the outlook of Burundian social life (Laely 1997; Lemarchand 1995). A second historical element is the fact that social organisation beyond the family has been minimal in Burundi: Burundians lived scattered on the hills in their isolated homestead or rugo, and not in villages (Uvin 2009: 69-70). Third, most 'formal' associational life that did exist was enforced from above, and left a negative impression: e.g. 'paternalistic' cooperatives under Belgian colonial rule (BadiononaTshondo 1993), and the Bagaza regime (Second Republic, I976-87) controlling the peasantry through cooperatives and villagisation (attempt to centralise the rural masses into villages) (Lemarchand i995). In addition, the Burundian state has made considerable efforts to destroy social capital not under its control, the most famous case being the muzzling of the Catholic Church during the I980s (Longman 2005). Burundi has also been confronted with the 'dark side' (Portes \& Landolt I996) of ethnically exclusive bonding social capital: several youth groups (Feunesse Nationaliste Rwagasore; Sans Echec, Sans Défaite) illustrate how civil society groups have adopted a genocidal logic and taken part in ethnic violence (Daley 2008). In sum, the Burundian people have little experience in voluntary, bridging associational life at grass-roots level. Instead, they have generally negative feelings towards the forced (cooperatives, villagisation), suppressed (conflict with the church), or dark (ethnic youth militias) character of associational or other collective action experiments.

Ethnic violence, and the civil war from 1993 onwards, influenced social capital endowments in two ways. On the one hand, ethnic strife clearly destroyed existing stocks of social capital. Massive displacement tore apart families and community life: recent statistics indicate that $52 \%$ of the total population have fled their homes at least once since I993 (Uvin 2009: 29). The crisis led to a general decline of mutual help and solidarity, and a further segmentation of economic groups (rich/poor) (ibid.). On the other hand, civil war also transformed social capital. During the civil war, most 
of Burundi was divided into Hutu and Tutsi 'enclaves' or 'colonies' (Laely 1997: 695). The capital Bujumbura was divided into Hutu and Tutsi quartiers; walking through the wrong district meant certain death. In the countryside, the Tutsi population fled to secure Internally Displaced Persons (IDP) camps, while the Hutu population was forcefully displaced into camps de regroupement (HRW I998). In social capital terms, one could speak of a country of 'weak bridges, strong bonds', in which inter-ethnic bridging interactions were replaced by more inward-looking ethnic bonding ties, resulting in an 'us versus them' rhetoric (Brachet \& Wolpe 2005: 6).

Paradoxically, since 1993, and even more since the Arusha peace agreements of 2000, grass-roots associations have mushroomed across Burundian hillsides. The explanation is twofold (Sebudandi \& Nduwayo 2002). On the one hand, civil war pushed the Burundian population even more towards self-help and mutual help, since the capacity of the state to deliver basic public services deteriorated dramatically. On the other, the proliferation of associations was externally driven, coinciding with the arrival of various international and multilateral aid agencies, donors and NGOs. As a general strategy, the international community used bricksand-mortar projects as a 'vehicle to address social issues, by strengthening inter-group trust and the capacity of communities to collaborate effectively and manage conflict without resort to violence' (Brachet \& Wolpe 2005: 4). As prescribed by social capital literature, bridging multi-ethnic community associations were at the centre of this approach (for an elaborated illustration see Rupiya \& Schuller tot Peursum 2009). The emergence of a vibrant civil society at grass-roots level, promoting reconciliation and community development, was therefore seen as a positive evolution and part of a conflict-sensitive development strategy for Burundi (Brachet \& Wolpe 2005: 7).

THE CASES: INTRODUCING NEW 'INSTITUTIONAL SETTINGS'

Data and analysis are based on ten months of fieldwork on three collines (hillsides, administrative units) in 2006 and $2007 . .^{3}$ Each of the collines presented an illustrative 'typical case' (Patton 2002: 236) of the different interventions of three development agencies: Burara (CIBA), Tangara (LITA) and Cumba (CLC). ${ }^{4}$ The fieldwork was carried out in cooperation with a team of local research assistants by conducting focus group discussions and semi-structured interviews. ${ }^{5}$

CIBA, LITA and CLC are three American-based international NGOs that introduced livelihood projects under the umbrella of the Livelihood 
Security Initiative Consortium (LSIC), funded by the United States Agency for International Development (USAID) (LSIC 2004). ${ }^{6}$ The overall objective of LSIC was the support of sustainable livelihood strategies through agricultural production, livestock restocking, and natural resource management. The projects were implemented in the north of Burundi between 2005 and 2007, and are illustrative for reconstruction efforts in Burundi: livelihood interventions are identified as appropriate instruments to implement post-conflict reconstruction policies in protracted crisis situations (Russo et al. 2008); their focus on food security aligned well with the Burundian context of protracted food insecurity and the critical role of the agricultural sector in the livelihoods of Burundian households. Because of the Consortium construction, all three NGO projects had a similar focus.

The strengthening of community associations was linked to two particular objectives of the Consortium project proposal. On the one hand, associations were used to create new economic opportunities through the promotion of agro-enterprise development and income-generating activities. On the other, they were used to reduce community conflicts. For all consortium partners, strengthening associational life, with special attention to the ethnic and gender dimensions, was a strategy to increase local capacity for conflict resolution. In fact, the number of associations and the number of households participating in associational life are the only two indicators to measure this specific objective of community conflict reduction (Morinière et al. 2007: 25-6). ${ }^{7}$ As such, the Consortium proposal fits well the 'liberal peace' policy agenda, which urges NGOs to combine economic and social reconstruction, turning their aid into a strategic tool for conflict resolution (Duffield 2002; Goodhand 2006). Furthermore, it subscribes to the hypothesis that associations are able to combine addressing concrete practical concerns (e.g. income-generating activities) with reconciliation of adversarial parties (e.g. reduction of community conflicts) through repeated social interaction (see e.g. Pickering 2006: 79).

Although all three NGO-projects had a similar focus, it was still possible to make a fruitful comparison, as the three agencies had different philosophies on the use and utility of community associations, as will become clear throughout the case studies.

\section{CIBA on Burara colline: associations as technical subcontractors}

The first case-study is the intervention of CIBA on Burara colline. This colline is located near the administrative centre of Busoni commune, which 
links both sides of the hills surrounding the Muhembezi wetland. A large IDP camp straddles both sides of the wetland. For several reasons, Burara colline, and Busoni commune in general, have a clear ethnic segregation: a politically conscious Tutsi minority in the centre and a Hutu majority on the surrounding collines. First, Burara has a considerable group of resettled Tutsi near its centre (the IDP camps). In addition, this Tutsi group has direct links with national politics and the Tutsi elite in the capital. Several important figures within the Uprona (Tutsi) party originate from Busoni commune. Consequently, the local political struggle between the GNDDFDD (Hutu) party, which won the 2005 elections (also on a communal level), and the Uprona (Tutsi) party was particularly intense, while ethnic tensions remained prevalent in the commune. Busoni commune therefore was an exception in northern Burundi, in which the GNDD-FDD in general held a very strong position (as was the case on the other studied collines). Nevertheless, this local political struggle did not substantially affect the functioning of the community associations related to the CIBA project. As will become clear, this can be explained through CIBA's close technical follow-up of the community associations, leaving minimal room for local political power relations to influence their functioning.

Of the three development agencies studied, CIBA had the most explicit focus on technical end results such as improved irrigation systems in the wetlands, water tap infrastructure, anti-erosion measures and road protection, improvement of local livestock by cross-breeding, and the certification of improved rice seed varieties. This was reflected in the staff policy, as technical staff (agronomists, veterinarians, engineers) outnumbered social workers. In comparison with the other studied projects, CIBA therefore followed a rather top-down approach to achieve these technical end results: each specific technical end result was closely followed and monitored by one particular technical staff member - a constructional engineer for the irrigation system, a forester for the anti-erosion measures, a veterinarian for the livestock component, and so on. As a consequence, technical staff were present daily on the collines to follow up the project activities. This 'technical' focus also substantially guided the constitution of the community associations, as associations were clearly linked to specific technical project objectives.

A first illustration of this technical approach are the anti-erosion associations. Because of deforestation and extensive land use, each season heavy rains cause floods, landslides and further degradation of the soil. Anti-erosion measures (contour lines and hedges) had previously been executed through food-for-work (FFW) and cash-for-work (CFW) programmes, also under the supervision of CIBA and the World Food 
Programme (WFP) in Burara. After the FFW programme stopped, CIBA preferred to make past efforts sustainable, raising public awareness to create one anti-erosion association for each colline, since soil protection was best organised by geographical entities. Although the associations were set up, the population did not accept these changes. Until that time, food aid compensation was the main incentive for the people involved. In their minds, associations represented a continuation of the FFW programme, as they expected to receive the same incentive (food aid) for the same work (contour lines), but delivered through a new channel or 'gateway' (via the association instead of individually). For them, the new associations were technical subcontractors, which should be paid according to the delivered services within the scope of the livelihood project. The fact that there was little or no coordination among the intervening actors made the situation even more complex, as other NGOs did compensate for the anti-erosion works on neighbouring hillsides. CIBA also had contradictions in its own approach. While staff tried to motivate the population to implement antierosion activities without payment, other staff paid the wages of the casual workers repairing the roads. Thus, when it became clear that food compensation would not follow, most of the anti-erosion associations stopped their activities and ceased to exist.

A second type of association facilitated the implementation of the rice programme in the Muhembuzi wetland. First, water user committees were established to maintain the irrigation system. Second, these committees were transformed into rice farmer groups to ease the technical support and to structure the rice programme. Third, all sixty-nine rice farmer groups were united into a single rice cooperative, to ease the commercialisation of rice production, and improve market access. These stages clearly illustrate the assumed linear progression of community associations as mentioned in the theoretical section: bonding social capital (the ability to maintain local efforts in the management of the irrigation system) is complemented by bridging capital (the ability to create bridges and unite all rice farmers in the wetland) to create linking social capital (the ability to influence the rice market through the rice cooperative). However, also in this case, associations functioned as new 'aid gateways'. On the one hand, people accepted the new social infrastructure of water user committees, rice farmer groups and the cooperative because CIBA promised to buy up the rice production during project years. On the other hand, community associations served as temporary intermediaries to transfer knowledge, skills and technology. As one farmer argued: 'The associations were founded because of CIBA's aid. Now, we know about modern agriculture. If the aid is working, we will use this knowledge for our own fields, but the associations will stop 
existing' (focus group, 20.04.2007, CIBA project, Burara). Indeed, once the project had finished, the majority of the rice farmer groups ceased to exist. $^{8}$

In all cases, CIBA used associations in specific situations where collective action problems arose: natural resource management (the maintenance of the irrigation system in the wetland and anti-erosion measures on the hillsides) (e.g. Krishna \& Uphoff I999; Pretty \& Ward 200I), and the commercialisation and marketing of agricultural production (the rice programme in the wetland) (e.g. Bebbington \& Carroll 2000; Sorensen 2000). However, these associations never merged with existing social capital endowments. Most associations remained exogenous or 'alien' institutional settings, having a reason for existence only within the scope of the CIBA project.

To a great extent, this lack of institutional syncretism (cf. Galvan 2007) can be explained by the fact that the associations, as new institutional settings, were designed with reference to external technological end results, rather than to local social capital endowments. In all three cases, their constitution and composition were based on technical criteria. For example, in the wetland, farmers were asked to form groups of thirty people with adjacent plots: these criteria of proximity and group size were based not on prior social organisation, but on maintaining the newly introduced irrigation system. The same holds true for the antierosion association: the fact that its scope coincided with the boundaries of Burara hillside was not a social but a geographical demarcation, based on the technical feasibility of the anti-erosion measures. None of these criteria, however, guaranteed the existence of a 'social basis' to maintain this technical collaboration among community members. Because of their close connection to technical end results, the newly created community associations were initially perceived as new 'aid gateways' - i.e. channels for the development agency to achieve technical project goals, or for the local population to access support from the external agency.

However, with regard to post-conflict reconstruction, the associations did succeed in creating bridging ties between the different ethnic groups. The NGO kept lists indicating the multi-ethnic and gendered character of both the associations and their committees; all associations included both Hutu and Tutsi. Some associations even had Twa members, an often forgotten and extremely deprived ethnic minority in the past. But the creation of bridging associations presented a potentially 'false sense' of inclusiveness. As already mentioned, the Busoni community has a segregated ethnic outlook: most Tutsi live in the centre, whereas most Hutu 
live in the surrounding hillsides. Because of this clear geographical segregation, and the presence of a large group of Tutsi in the centre, ethnicity still played a key role (compared with the other hills studied). As a result, most associations were Tutsi (centre) or Hutu (hills) dominated. Members openly indicated that they sought extra Tutsi or Hutu to make their association multi-ethnic because CIBA asked for it. They called them Hutu or Tutsi figurants (or 'bit players'). Although this did not result in exclusion or ethnic tensions within associations, it does indicate that their multi-ethnic character was to some extent artificial, in order to meet CIBA criteria, and did not represent the actual situation on the ground. Moreover (as highlighted above), the potential 'bridging' effect of these associations was not sustainable: the anti-erosion associations ceased to exist during the project, while a considerable number of rice association ceased to exist after the project.

\section{LITA on Tangara colline: associations of the elite}

The second case study is the intervention of LITA on Tangara colline. Of the three studied collines, Tangara was most clearly a GNDD-FDD stronghold. In Tangara ethnic tensions were not as prevalent as in Burara, and the 2005 elections presented a more 'classical' political party struggle between Frodebu and GNDD-FDD. GNDD-FDD won these elections with a clear majority, which meant that 'the party' was omnipresent and had an evident militant character.

LITA's project in Tangara was set up around the construction of le hangar, a storage facility for agricultural production. It was managed by a committee representing local community associations in Tangara, and was responsible for the core activity of the LITA project: a seed credit system with local agricultural producers. LITA asked the local population to form associations, after which they received a seed credit of beans, peanuts etc. Afterwards, the associations reimbursed the credit to the committee for the hangar, which used it to supply other groups.

LITA was the Consortium member which focused most on participatory group-oriented processes, and was a strong advocate of an 'associational' approach: associations were identified as the main endbeneficiaries, storehouses were opportunities to create local structures of cooperation and collaboration, and great efforts were made to support these participatory processes. The end goal of the project was the participatory process rather than technical end results. As a consequence, the staff composition was the opposite of CIBA: social workers outnumbered 
technical staff, and local NGO staff was less visible in the field, as rigorous technical supervision by NGO staff was less necessary.

In terms of the intervention strategy, this translated into a more bottomup laisser-faire approach in introducing community associations. In contrast to CIBA, LITA used a relatively open-ended approach for the creation and development of community associations. Their use was not linked to specific technical end results: LITA only required the associations to be agricultural, multi-ethnic and formalised (registration, statutes and so on). Apart from these requirements, all community members could create or join an association and each association could define its own goals and activities. To motivate the population, LITA offered the associations seed credits and the storage facilities in the hangar.

In other words, unlike CIBA, LITA went beyond a technical approach, and left more room to integrate the associations into community social life. In doing so, an attempt was made to merge an exogenous approach with local dynamic processes of social capital. However, LITA still encountered major problems. The reason was that associations, as new institutional settings, did not develop into 'building blocks' of bridging social capital. Instead, they reproduced locally 'unresponsive' linking capital (Putnam 2004: 669), manifest in personalised patron-client ties. This began with the problem of elite capture.

Elite capture of community associations had some history on Tangara colline. People explicitly referred to the breaking up of the 'mother of all associations', Twiyungure, to explain where and when this problem began. The Twiyungure association started in an IDP site near Rugari in Muyinga province, to which Tutsi from Tangara fled after the 1993 violence. When the security situation improved, these Tutsi returned to a resettlement camp in Tangara, and brought their association with them. At that time, it was the only association in Tangara colline, and was supported by WFP. It was subsequently audited and found to be mismanaged, before the president disappeared with the association's funds. Instead of staying unified in one association, several members of the committee of Twiyungure, who belonged to the local elite, took advantage of the situation and formed their own association, motivated by a possible collaboration with the WFP. The 'associational logic' in accessing aid was therefore already understood by the local elite. In addition, with the arrival of LITA's livelihood project access to project benefits was made conditional on membership in associations. As such, the local elite applied the same 'associational logic', many of them becoming presidents of their own newly created associations to access external aid. The strong position of the local 
CNDD-FDD political elite and administration was another factor which enhanced elite capture.

In the case of the LITA project, most of the associations were captured by le club d'hangar or 'the storehouse committee': a small group of local petty traders and members of the local administration under the leadership of the chef de colline. This committee centralised the control and supervision of project activities; in particular, all LITA seed credits were channelled through the storehouse. The powerful intermediary role of the club was based on the fact that committee members played two different roles: they not only distributed the seed credits among the associations but also received seed credits as presidents of their own associations. Therefore, the local elite occupied most leadership positions in both the associations and the storehouse committee.

This problem of elite capture had two main consequences. First of all, most associations had problems of internal mismanagement. The democratic character of the associations was minimal: presidents rarely accepted criticism, there were no information meetings, members were not informed about the financial situation, and presidents made financial transactions without any control. There were many reports of corruption and embezzlement of project funds. The question then is: why did ordinary members still accept these associations? Some associations did cease to exist, but most carried on. The reasoning of the members reflected the 'pareto improvement' argument of Platteau (2004) in his work on elite capture in West Africa. They preferred unfair practices within their associations while still receiving some aid, rather than quitting the associations and losing all hope, as membership of the association still yielded a pareto improvement (ibid.: 227). Both parties were also dependent on each other: the elite needed farmers to populate their associations, farmers needed a member of the elite with links to le club d'hangar.

A second consequence of elite capture of the community associations was its impact on the broader community. The associations not only created internal problems, but also pitted different groups against one another within the community. Associations worked exclusively rather than inclusively. First, their unparalleled splitting and multiplication created jealousy and tensions between them. Membership was kept to a minimum in order to maximise profits. A teacher (Tangara 2007 int.) of the local primary school said:

Mostly, the creation of associations is done secretly, not everyone can join. If you're not a friend of the creator [of the association], you can't know an association has been created, and if you ask thereafter to join, he will ask a 
high contribution. Then they are sure that other people will not come to their association and that the benefits are for a small group of people.

As a consequence, new associations popped up at regular intervals, increasing competition between them to access external aid. In this respect, the situation in Tangara reflects an inverse evolution - the opposite - of the assumed linear progression of community associations. Instead of opening up to new members or seeking synergy with other associations (transforming bonding into bridging social capital), the multiplication of associations further fragmented the social arena in Tangara commune (creating more of the same bonding social capital). Second, a vast majority of poor people who simply could not afford to pay the membership fees or were not 'invited' by the elite to join an association felt excluded from the LITA project, as they received no benefits at all. In their perception, the associational strategy of LITA deprived them of fair and equal development opportunities. It was clear to them that if LITA wanted to include everybody, this could not be achieved via associations.

In sum, community associations did succeed in syncretising with local endowments of social capital. Unfortunately, they reproduced 'unresponsive' linking social capital (Putnam 2004: 669; Titeca \& Vervisch 2008). On the one hand, the internal organisation of many associations mirrored existing vertical relations between patrons (president/ committee) and clients (ordinary members), resulting in mismanagement and a lack of accountability and participatory decision-making processes. On the other, and in line with the 'critical' civil society literature, associations reproduced existing power structures within the community, and intensified feelings of exclusion, because of elite capture.

This in turn questions the ethnic focus when promoting bridging community associations. As the Burundian conflict is analysed as an ethnic conflict, most post-conflict activities focus on reconciling the two main ethnic groups. However, members of these associations in Tangara, when consulted, immediately mentioned that ethnic groups and women were both represented; they were even more proud that Twa were also members of their association (cf. CIBA in Burara). They knew how external actors analysed 'their' conflict, and therefore automatically used this discourse. Still, ethnic tensions never caused problems in the associations, and in this way they succeeded in creating bridging capital.

However, the associations did create economic exclusion. Access to project funds through community associations was a privilege of the local elite, while the vast majority of the community was excluded from membership. This exclusionary governance of associations resulted in a concrete example of structural violence, as discriminatory access deprived 
people of new opportunities to enhance their situation. This triggered tensions within the community, but not along ethnic lines. ${ }^{9}$ The LITA case therefore illustrates how a tailored focus on multi-ethnic associations may create a 'false sense' of inclusiveness on the ground (the multi-ethnic and bridging character of the associations). It may also neglect or reproduce a more general, deep-seated problem of social exclusion (the exclusionary and 'unresponsive' linking character of the associations), because it produces economic, rather than ethnic, exclusion.

\section{CLC on Cumba colline - a hillside without associations}

The third case study is the intervention of GLG on Cumba colline. At the political level, the 2005 elections also brought a clear victory for the CNDD-FDD in Cumba: the party controlled almost all administrative positions. But in contrast to Tangara, at the time of research the party was not militant at all, and people dissociated themselves from it and mistrusted party members. The main reason was the general mistrust and fear of the ruling CNDD-FDD party, after the killing of thirty-one civilians in the region by the army and Service National de Renseignement (SNR), because of alleged collaboration with the FNL rebels (HRW 2006: I8). Therefore, the population's support and enthusiasm for the GNDD-FDD party rapidly decreased after the elections, and local administration did not hold a strong position on Cumba colline.

All three NGOs used the Livelihood Consortium to switch to a more long-term development logic, by rolling out sustainable household livelihood strategies. However, CLC on Cumba colline most clearly translated this shift into a reduction in the distribution of material resources: in contrast to CIBA's 'technical' and LITA's 'associational' approach, CLC focused on changing individual behaviour and attitudes, and enhancing personal knowledge, capacities and skills. CLC thus opted for a close and constant follow-up of 'lead farmers' by its encadreurs de base, who are people living among or close to the target population, and who function as the contact between the population and provincial CLC staff. In addition to the political difficulties with the GNDD-FDD party, representing an absent and unpopular local administration, this focus on individual households and the strong position of the encadreurs de base also left little room for local administration to cooperate in the CLC project. CLC's focus on 'individual change' explains their choice of working with individual households, instead of associations.

The CLC intervention therefore gave us the opportunity to observe what happened when no external agency was raising awareness and 
motivating the population to create new associations. As might be expected, almost no associations were found in Cumba. As highlighted above, the main incentive to create new associations in Burara (CIBA) and even more in Tangara (LITA) was the project aid accessed through these associations. The CLC intervention confirms this general observation, by turning the argument upside down: precisely because external intervention did not channel project aid through associations, associations were almost non-existent on Cumba colline. According to the local population, the raison d'être of associations is to receive aid. As one man explained: 'There are not many associations because even the associations that exist did not succeed once to get help from a NGO. That's why people abandon their associations and no new associations are created' (Focus group, Cumba 2007 int.). People also explicitly referred to the importance of patrons who could act as gatekeepers: there was a lack of people willing to introduce the associations to external agencies in order to receive aid. As there was no incentive for the elite to interfere with the creation of associations, the local elite was much less involved in associational life and no elite capture was mentioned by the population. By contrast, the population of Cumba blamed the local administration for a lack of initiative because they did not approach NGOs to gain support for associations, something which also reflected the more general deterioration of relations between the GNDD-FDD administration and the local population.

The CLC intervention thus shows how reasons, incentives and motivations to create associations on Cumba colline had become structurally adapted to the presence of external assistance. CLC was even criticised because it did not work through associations like other international organisations. This reasoning was based on various experiences. First, CLC had worked with associations in the past, and the population urgently asked the organisation to start supporting associations again. However, this 'opportunistic' intention to access project aid through associations was exactly the reason why CLC stopped their support. Second, the population compared their situation with other hillsides: 'Here we don't get [aid]. We hear that associations on other hillsides are supported and get aid. Why don't the NGOs come here to support the associations? If they come, a lot of associations will be formed' (Focus group, Cumba 2007 int.). Lastly, people compared the CLC project with other projects, for example the Agricultural Rehabilitation and Support Project (PRASAB) of the World Bank that was in its initial phase. This nationwide project was based on a grant system. Local associations could submit a grant proposal to a provincial committee to implement agricultural or livestock 
activities. For the population, this was a 'promising' project, as associations would be linked to a concrete incentive, so creating the association was clearly worthwhile. For the population of Tangara it was ultimately clear that no associations would grow without external interest; this was confirmed by the small number of 'only' three associations on Cumba colline.

The Cumba case illustrates the possible long-term effects of the general policy of external actors in Burundi to support the creation of associations. The externally driven character of the proliferation of associations in Burundi has already been noted (Sebudandi \& Nduwayo 2002). As a consequence, the widespread perception of associations as 'gateways' to aid highlights the general vulnerability of externally driven associations. It reflects a situation in which sustained exposure to exogenous new 'institutional settings' (external agencies promoting community associations) can change endogenous local dynamics of social capital building. In the long term this may reduce local dynamics of social organisation, as it becomes less likely that community associations will be nurtured without external incentives in the future (Crowley et al. 2005: I5).

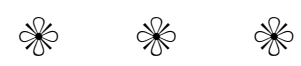

All three case studies highlight different problems in the constructability of social capital, and more particularly, the failure of the three interventions to initiate a fragile process of 'institutional syncretism'. First, CIBA illustrates how an exogenous process of social capital building can remain exogenous. A 'strong' social engineering approach led to 'alien' associations, i.e. externally introduced 'institutional settings' which never merged with locally produced social capital endowments. With its focus on technical end results, CIBA gave the local population few opportunities to adapt their social life to the newly introduced institutional settings. The associations never disassociated from the project, functioning as technical subcontractors.

Second, LITA illustrates how an exogenous process of social capital building can merge with endogenous social capital endowments; but this does not automatically bring positive effects: their 'soft' social engineering approach (bottom-up and open-ended) led to 'uncivic' associations, as they adapted towards locally produced 'unresponsive' forms of linking capital. Through LITA's soft approach, room was left for the local population to merge the new institutional setting of the associations with local norms and rules of social organisation. Because of elite capture, the associations became too embedded in existing vertical patron-client ties. 
Finally, CLC demonstrates how endogenous social capital endowments may be adapted towards exogenous processes of social capital building. It shows how a policy of external support in creating organisations for the poor affects the broader environment and diminishes local dynamics of the poor in organising themselves (Crowley et al. 2005: 17).

Our critique of 'social engineering' (or the 'technical fix') of community associations does not mean that external interventions are automatically flawed. Any external development intervention is de facto about 'social engineering'. In line with the 'critical' literature on civil society, the above cases rather show that using community associations as 'universal blueprints' leads to 'institutional monocropping': the replacement of local social dynamics and practices with those of more advanced societies, without tailoring these to the local context (Evans 2004). Equally, the cases show that existing endowments of social capital need to be approached with great care, as they can have a profoundly negative effect. They should not automatically be preferred above exogenous 'institutional settings' simply because of their 'local' character. Institutional syncretism therefore is an extremely fragile exercise, which is summarised in this section.

On the one hand, there is the problem of overly ambitious external initiatives of 'social engineering' of social capital and community associations. First, development practice to a great extent is driven by the culture of the organisations and their attempts to present their actions as examples of authorised policy (Mosse 2004). The aims of all three Consortium partners in playing their role of 'institutional entrepreneur' and strengthening multi-ethnic social cohesion reflects their attempt to present their work as examples of contemporary post-conflict reconstruction policy. This policy prescribes the integration of economic and social reconstruction, i.e. the restoration of social cohesion and local conflict resolution capacity while bringing development (Duffield 2002). In addition, the organisational cultures and philosophies of the different Consortium partners substantially guided the practical realisation of this objective: CIBA's 'technical' focus explained the rather technical finality of most of the associations on Burara colline, while LITA's focus on participatory group processes explained their clear 'associational' approach, and CLC's emphasis on 'individual change' their choice of working with households and not with associations. Second, the three cases highlight the importance of the 'right' tangible incentives and the functioning of 'incentivised voluntarism' (Gillinson 2004: 6). All three cases have at least one issue in common: community associations were primarily perceived as 'gateways' to aid: people's voluntarism was incentivised, as the project aid 
redirected members' motivations. The cases generally indicate that the incentive should be designed as an initiator but not as the most important motivator of participants' behaviour; the external incentive has to be substituted by an internal incentive (which should preferably be more attractive). Development agencies need to tailor their incentives, adapting them to the local situation. At present, they are driven more by the need to disburse funds and distribute resources, rather than focusing on the local dynamics of associational life, i.e. they need to act in keeping with policy and donor logics, more than with the needs on the ground (cf. de Sardan 2005: I4I).

On the other hand, the above cases show how even within the same region, three external interventions generate very different results on three different collines; and therefore show the importance of detailed contextual knowledge of prior social capital endowments. On each of the three collines there was a different interplay between the intervention and the local political settings. In Tangara, the strong position of the CNDD-FDD party went hand in hand with the elite capture of community associations during project implementation. In Cumba, the blaming of the local administration for not looking for donor aid to create local associations partly reflected the more general friction between the local population and the GNDD-FDD party. In Burara, next to the technical focus and close follow-up of the NGO, the strong (geographical) ethnic segregation revealed the donor-driven and 'artificial' sense of inclusiveness: in reality most associations were Tutsi (centre) or Hutu (hills) dominated, and many ceased to exist during or after the end of the project. In general, the brief historical summary shows why vibrant community associations are not self-evident in Burundian society. It highlights how: (a) patron-client ties play an important role; (b) social organisation is weak beyond the family; and (c) the civil war shattered social cohesion and organisation. It enables us to better understand why associations did not evolve as expected. This is not to say that associations, as new 'institutional settings', cannot become a promising element in the further development of Burundian society, as this would follow a radical 'endowment' view, in which societies are rigid and can only change over longer periods of time. Still, it reminds us not to underestimate the thriving force of history.

In summary, if one accepts that development projects within a context of 'liberal peace' are always about 'social engineering', the above cases indicate that the real challenge lies in developing new 'institutional settings' that are 'soft' enough to adapt to prior social capital endowments, but 'strong' enough to change or reinforce these endowments to bring positive results. In sum, the task is to avoid both the absence (cf. the CIBA 
case) and 'excess' (cf. the LITA case) of institutional syncretism (Galvan 2007: 70).

With regard to post-conflict reconstruction, the three described case studies question the ability of the 'liberal peace' model to produce the desirable outcomes desired by donors and the international community, precisely because this fails to reach such institutional syncretism and is instead caught in 'universal blueprints' of institution building - or 'institutional monocropping' (Evans 2004) - to favour processes of democratisation and post-conflict reconstruction.

The general idea of multi-ethnic 'bridging' associations sheds some light on the matter. First, our micro-level analysis of the difficulties of building bridging associations in three communes demonstrates how the development of outward instead of inward legitimacy generates substantial problems: legitimacy is developed towards external donors rather than the 'inward' constituency. Concretely, the idea of 'ethnic inclusiveness' is developed more for the donor audience than for the ethnic groups as such: in the case of CIBA, the multi-ethnic character of the newly created associations was unrelated to the actual ethnically segregated and sometimes tense situation in the community. These processes of external legitimacy also created problems of accountability and participation within the associations: in the LITA case, the 'false sense' of inclusiveness even worked as a smokescreen, as these multi-ethnic 'bridging' associations reproduced the more fundamental problem of 'unresponsive' linking social capital, resulting in economic instead of ethnic exclusion.

Second, in line with the critique on community associations within the liberal peace model, it has become clear that community associations are no 'universal blueprints' to create social capital (e.g. Molenaers 2003), but are deeply embedded in their social and political context, reproducing existing tensions and power structures. Uvin (2005) argues that the introduction of such institutions at a national level in Burundi has installed a liberal-democratic façade, without substance or content, as the existing system and power structures undermine the imported system from the inside out. The LITA case describes exactly the same process on a micro-scale, with a disconnection between the structural and cognitive components of social capital (Molenaers 2003: II4). Moreover, although a multitude of bridging community associations were present (structural component, as a liberal-democratic 'façade'), these were disconnected from their horizontality and embedded trust (cognitive component), and adjusted towards the existing 'system' of vertical power relations. As such, the idea of bridging associations in the Burundian context presents us with a micro-manifestation of one of the main shortcomings of this 'liberal 
peace' model: its incapacity and unwillingness to enter into dialogue and syncretise with local institutional settings. In doing so, international donors therefore fail to acknowledge to existence of local resources and make local development dependent on international presence (Belloni 2007: I I I).

\section{NOTES}

I. On the history of conflict in Burundi see Daley 2006, 2008; Lemarchand I995, 2009; Reyntjens I993, 2000; and Uvin I999, 2009.

2. See for example the World Bank website on the Social Capital Initiative, http://go.worldbank. org/XSV7oMA6oo, accessed 2.I0.2009.

3. Clearly, this case-study approach does not allow for generalisations for the entire scope of the projects, or for the whole of Burundi or other external interventions.

4. For the sake of discretion the identity of the different NGOs is not disclosed. We use pseudonyms, which stand for Consortium Inititative Burara (CIBA), Livelihoods Tangara (LITA) and Cumba Livelihood Consortium (CLC).

5. To determine the number of focus groups, we used the concepts of redundancy and theoretical saturation (Krueger \& Casey 200I). Generally between six to ten people participated in the focus groups, which conforms to the rule of thumb (Patton 2002: 385 ). In total, eighty-one focus groups were conducted with a total of 693 participants. In addition, seventy-seven interviews were conducted with key actors (NGO staff, local administration etc.).

6. The LSIC was a collaboration of four NGOs. It was present in four northern and central provinces: Gitega, Karuzi, Muyinga and Kirundo. For practical (time and financial) and methodological (similar context, different intervention strategies) reasons the research focused on three NGO projects in the northern provinces of Kirundo and Muyinga.

7. This is a clear example of how 'counting associations' is used as a proxy indicator (or a short cut) to measure all kinds of complex social processes (in this case, local capacity for conflict resolution). It reflects both the demand from donors to present measurable results (numbers and percentages), and the popularity of Putnam's equation of social capital with associations, precisely because it makes social capital a measurable concept in the hands of policy makers.

8. Personal communication with technician of ISABU (Institut Supérieure de l'Agronomie Burundais) working in particular with the farmers of the Muhembuzi wetland, May 2008.

9. An illustrative example on this point was the fact that both the current (CNDD-FDD party and Hutu) and former (Uprona party and Tutsi) chef de collines were members of le club d'hangar and controlled much of the project benefits together.

\section{R E F E R E N C E S}

Badionona-Tshondo, J. M. V. i993. 'Problématique de la gestion des cooperatives au Burundi: cas spécifique des Coopératives d'Approvisionnement et de Commercialisation' ('The problem of the management of cooperatives in Burundi: the specific case of the Cooperatives for Supply and Commercialisation'), memo, Institut Supérieur de Développement Rural, Bukavu.

Bastiaensen, J., T. De Herdt, \& B. d'Exelle. 2005. 'Poverty reduction as a local institutional process', World Development 33, 6: 979-93.

Bastiaensen, J., T. De Herdt, \& J. Vaessen. 2002. 'Poverty, institutions and interventions: a framework for an institutional analysis of poverty and local anti-poverty interventions', IDPM-UA Discussion Paper 2002-6, Antwerp: Institute of Development Policy and Management.

Bebbington, A. \& T. Carroll. 200o. 'Induced social capital and federations of the rural poor', Social Capital Initiative Working Paper I9, Washington, DC: World Bank.

Beck, L. 2003. 'Democratisation and the hidden public: the impact of patronage networks on Senegalese women', Comparative Politics 35, 2: 147-69.

Belloni, R. 200I. 'Civil society and peacebuilding in Bosnia and Herzegovina', foumal of Peace Research 38, 2: 163-80.

Belloni, R. 2007. State Building and International Intervention in Bosnia. New York: Routledge. 
Belloni, R. 2008. 'Civil society in war-to-democracy transitions', in A. Jarstad \& T. Sisk, eds. From War to Democracy: dilemmas of peace building. Cambridge University Press, I82-2 Io.

Bierschenk, T., J. P. Chauveau, \& J.-P. O. de Sardan. 2000. Courtiers en Développement: les villages africains en quête des projets. Paris: Karthala.

Blaney, D. \& M. K. Pasha. I993. 'Civil society and democracy in the Third World: ambiguities and historical possibilities', Studies in Comparative International Development 28, I : $3^{-24}$.

Brachet, J. \& H. Wolpe. 2005. 'Conflict-sensitive development assistance: the case of Burundi', Social Development Paper 27, Washington, DC: World Bank.

Brown, L. D. I99I. 'Bridging organizations and sustainable development', Human Relations 44, 8: $807-3$ I.

Colletta, N.J. \& M. L. Cullen. 200oa. 'The nexus between violent conflict, social capital and social cohesion: case studies from Cambodia and Rwanda', Social Capital Initiative Working Paper 23, Washington, DC: World Bank.

Colletta, N. J. \& M. L. Cullen. 200ob. Violent Conflict and the Transformation of Social Capital: lessons from Cambodia, Rwanda, Guatemala, and Somalia. Washington, DC: World Bank.

Colletta, N. J., M. Kostner \& I. Wiederhofer. 1996. The Transition from War to Peace in Sub-Saharan Africa. Washington, DG: World Bank.

Crowley, E. et al. 2005. 'Organizations of the poor: conditions for success', paper prepared for the International Conference on Membership-Based Organizations of the Poor: Theory, Experience, and Policy, Ahmedabad, India, I7-2i January.

Daley, P. 2006. 'Ethnicity and political violence in Africa: the challenge to the Burundi state', Political Geography 25, 6: 657-79.

Daley, P. 2008. Gender $\mathcal{E}^{\circ}$ Genocide in Burundi: the search for spaces of peace in the Great Lakes region. Oxford: James Currey.

de Sardan, J.-P. O. 2005. Anthropology and Development: understanding contemporary social change. London: Zed Books.

Duffield, M. 2002. 'Social reconstruction and the radicalization of development: aid as a relation of global liberal governance', Development and Change 33, 5: 1049-7I.

Evans, P. I996. 'Government action, social capital and development: reviewing the evidence on synergy', World Development 24, 6: in I9-32.

Evans, P. 2004. 'Development as institutional change: the pitfalls of monocropping and the potentials of deliberation', Current Anthropology 38, I: I-24.

Fischer, M. 2004. 'Recovering from violent conflict: regeneration and (re-)integration as elements of peacebuilding', Berghof Research Center for Constructive Conflict Management, available at: http:// www.berghof-handbook.net/uploads/download/fischer_handbook.pdf, accessed 8.6.2009.

Fox, J. I996. 'How does civil society thicken? The political construction of social capital in rural Mexico', World Development 24, 6: 1089-1103.

Galvan, D. C. 2007. 'The social reproduction of community-based development: syncretism and sustainability in a Senegalese farmers' association', Journal of Modern African Studies 45, I: 6I-88.

Gillinson, S. 2004. 'Why cooperate? A multi-disciplinary study of collective action', ODI Working Paper 234, London: Overseas Development Institute.

Goodhand, J. 2006. Aiding Peace? The role of NGOs in armed conflict. Boulder, CO: Lynne Rienner.

Grootaert, C. I998. 'Social capital: the missing link', Social Capital Initiative Working Paper 3, Washington, DG: World Bank.

Henderson, S. L. 2002. 'Selling civil society: Western aid and the nongovernmental organization sector in Russia', Comparative Political Studies 35, 2: $139-67$.

Hooghe, M. \& D. Stolle, eds. 2003. Generating Social Capital: civil society and institutions in comparative perspective. Basingstoke: Palgrave Macmillan.

Hulme, D. \& M. Edwards. I996. 'Too close for comfort? The impact of official aid on nongovernmental organizations', World Development 24, 6: 96I-74.

Human Rights Watch (HRW). 1998. Proxy Targets: civilians in the war in Burundi. New York: HRW.

HRW. 2006. " "We flee when we see them." Abuses with impunity at the National Intelligence Service in Burundi', Report i8, 9(A), New York: HRW.

Krishna, A. \& N. Uphoff. I999. 'Mapping and measuring social capital: a conceptual and empirical study of collective action for conserving and developing watersheds in Rajasthan, India', Social Capital Initiative Working Paper I3, Washington, DC: World Bank.

Krueger, R. A. \& M. A. Casey. 200I. 'Designing and conducting focus group interviews', in R. A. Krueger et al., eds., 'Social analysis: selected tools and techniques', Social Development Paper 36 , Washington, DC: World Bank, 4-23. 
Laely, T. I997. 'Peasants, local communities, and central power in Burundi', Fournal of Modern African Studies 35, 4: 695-716.

Lemarchand, R. I995. Burundi: ethnic conflict and genocide. Cambridge University Press.

Lemarchand, R. 2009. The Dynamics of Violence in Central Africa. Philadelphia, PA: University of Pennsylvania Press.

Livelihood Security Initiative Consortium (LSIC). 2004. 'A proposal to USAID for the Livelihood Security Initiative Consortium’, Bujumbura, Burundi, 9 August.

Longman, T. 2005. 'Churches and social upheaval in Rwanda and Burundi: explaining failures to oppose ethnic violence', in N. Kastfelt, ed. Religion and African Civil Wars. London: Hurst, 82-Io.

Molenaers, N. 2003. 'Associations or informal networks? Social capital and local development practices', in M. Hooghe \& D. Stolle, eds. Generating Social Capital: civil society and institutions in comparative perspective. Basingstoke: Palgrave Macmillan, II3-32.

Morinière, L. et al. 2007. Evaluation Finale du Consortium SCVM. Bujumbura.

Mosse, D. 2004. 'Is good policy unimplementable? Reflections on the ethnography of aid policy and practice', Development and Change 35, 4: 639-7I.

Narayan, D. 1997. Voices of the Poor: poverty and social capital in Tanzania. Washington, DC: World Bank, Environmentally and Socially Sustainable Development (ESSD) series 20.

Ottaway, M. \& T. Chung. I999. 'Debating democracy assistance: toward a new paradigm', fournal of Democracy I0, 4:99-II3.

Paffenholz, T. 2009. 'Exploring opportunities and obstacles for a constructive role of social capital in peacebuilding: a framework for analysis', in M. Cox, ed. Social Capital and Peace-Building: creating and resolving conflict with trust and social networks. New York: Routledge, I86-20I.

Patton, M. 2002. Qualitative Research and Evaluation Methods. Thousand Oaks, CA: Sage.

Pickering, P. M. 2006. 'Generating social capital for bridging ethnic divisions in the Balkans: case studies of two Bosniak cities', Ethnic and Racial Studies 29, I: 79-103.

Platteau, J.-P. 2004. 'Monitoring elite capture in community-driven development', Development and Change 35, 2: $223-46$.

Platteau, J. P. \& Gaspart, F. 2003. 'The risk of resource misappropriation in community-driven development', World Development 31, io: I687-1703.

Portes, A. \& P. Landolt. I996. 'The downside of social capital', The American Prospect 26: i8-22.

Pretty, J. \& H. Ward. 200I. 'Social capital and the environment', World Development 29, 2: $209^{-27}$.

Putnam, R. D. I993. Making Democracy Work: civic traditions in modern Italy. Princeton, NJ: Princeton University Press.

Putnam, R. D. 1995. 'Tuning in, tuning out: the strange disappearance of social capital in America', Political Science and Politics 28, 4: 664-83.

Putnam, R. D. 2004. 'Commentary: "health by association", some comments', International fournal of Epidemiology 33, 4:667-7I.

Republic of Burundi (RoB). 2006. 'Poverty Reduction Strategy Paper', Bujumbura, Burundi, available at: http://siteresources.worldbank.org/INTPRS I/Resources/Burundi_PRSP(Sept2006).pdf, accessed 8.6.2009.

Reyntjens, F. I993. 'The proof of the pudding is in the eating: the June I993 elections in Burundi', Fournal of Modern African Studies 31, 4: 563-83.

Reyntjens, F. 2000. 'Burundi: prospects for peace', London: Minority Rights Group, available at: www.minorityrights.org/download.php?id= ${ }^{5} 53$

Robinson, M. I995. 'Strengthening civil society in Africa: the role of foreign political aid', IDS Bulletin 26, 2: 70-80.

Rubio, M. I997. 'Perverse social capital: some evidence from Colombia', Fournal of Economic Issues 3I, 3: $805-\mathrm{I} 6$.

Rupiya, P. \& A. Schuller tot Peursum. 2009. 'Community social contracts for disaster risk reduction in Burundi', paper presented at the World Conference on Humanitarian Studies, Groningen, 4-7 February.

Russo, L. et al. 2008. 'Food security in protracted crises: issues and challenges', in Alnovi, L., Hemrich, G. \& Russo, L., eds. Beyond Relief: food security in protracted crises. Rugby: Practical Action Publishing, I-I2.

Sebudandi, G. \& G. Nduwayo. 2002. 'Etude sur la stratégie et le programme d'appui à la société civile Burundaise' ('Study on the strategy and programme to support Burundian civil society'), unpublished report, Bujumbura: PNUD-Burundi.

Sorensen, C. 2000. 'Social capital and rural development: a discussion of issues', Social Capital Initiative Working Paper ı, Washington, DC: World Bank. 
Szreter, S. \& M. Woolcock. 2004. 'Health by association? Social capital, social theory, and the political economy of public health', International Fournal of Epidemiology 33, 4: 650-67.

Titeca, K. \& T. Vervisch. 2008. 'The dynamics of social capital and community associations in Uganda: linking capital and its consequences', World Development 36, II : 2205-22.

Uvin, P. 1999. 'Ethnicity and power in Burundi and Rwanda: different paths to mass violence', Comparative Politics 31, 3: 253-7I.

Uvin, P. 2005. 'A brief discussion of donor support to local governance in Burundi', unpublished report, Bujumbura, Burundi.

Uvin, P. 2007. 'Structural causes, development cooperation and conflict prevention in Burundi and Rwanda: a country case study', available at: http://www.wiltonpark.org.uk/documents/ conferences/WP889/participants/participants.aspx

Uvin, P. 2009. Life after Violence: a people's story of Burundi. London: Zed Books.

Varshney, A. 200I. 'Ethnic conflict and civil society, India and beyond', World Politics 53, 3: 362-98.

Woolcock, M. 2002. 'Social capital in theory and practice: reducing poverty by building partnerships between states, markets and civil society', in UNESCO, Social Capital and Poverty Reduction: which role for the civil society organizations and the state? Paris: UNESCO, 20-44.

Woolcock, M. \& D. Narayan 2000. 'Social capital: implications for development theory, research, and policy', The World Bank Research Observer I5, 2: 225-49.

\section{Interviews}

Focus group, CLC project, Cumba, 25.5.2007.

Teacher, LITA Project, Tangara, I6.3.2007. 
Reproduced with permission of the copyright owner. Further reproduction prohibited without permission. 